НАУКОВИЙ ВІСНИК

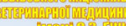

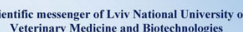

1

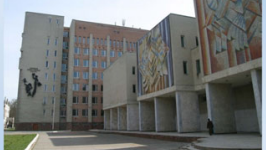

СЕРЯя ВЕТЕРИНАРН НАУКИ

RIES: VETERINARY SCIEN

Том 23 № 1

2021
Науковий вісник Дьвівського національного університету ветеринарної медицини та біотехнодогій імені С.3. Гжицького. Серія: Ветеринарні науки

\author{
Scientific Messenger of Lviv National University \\ of Veterinary Medicine and Biotechnologies. \\ Series: Veterinary sciences
}

UDC 619:615.11:612.397:612.11:612.336:637.7

\title{
Effect of fenbenzyl and fenbendazole on peroxide intensity oxidation of lipids in the blood of dogs in experimental toxocariasis
}

\author{
V. V. Stybel, B. V. Gutyj, W. S. Said \\ Stepan Gzhytskyi National University of Veterinary Medicine and Biotechnologies Lviv, Ukraine
}

Article info

Received 25.01.2021

Received in revised form 24.02.2021

Accepted 25.02.2021

Stepan Gzhytskyi National University of Veterinary Medicine and Biotechnologies Lviv, Pekarskaya Str., 50, Lviv, 79010, Ukraine.

Tel.: +38-068-136-20-54

E-mail:bvh@ukr.net
Stybel, V. V., Gutyj, B. V., \& Said, W. S. (2021). Effect of fenbenzyl and fenbendazole on peroxide intensity oxidation of lipids in the blood of dogs in experimental toxocariasis. Scientific Messenger of Lviv National University of Veterinary Medicine and Biotechnologies. Series: Veterinary sciences, 23(101), 107-112. doi: 10.32718/nvlvet10118

Toxocariasis is a chronic helminthic disease caused by the larval stages of the nematode Toxocara canis. The problem of toxocariasis is important for both humane and veterinary medicine. Therefore, the aim of the study was to investigate the effect of fenbenzyl and fenbendazole on the intensity of lipid peroxidation in the blood of dogs during experimental infestation with the pathogen toxocariasis. The experiments were performed on $18 \mathrm{dogs}$, two to four months of age, and three groups of six animals were formed in each: control and two experimental groups. Puppies of all groups were experimentally infected with the pathogen toxocariasis at a dose of 5.000 invasive T. canis eggs per $\mathrm{kg}$ of body weight. The control group of dogs was as untreated control. Puppies of the first experimental group were fed the drug "Fenbendazole" at a dose of $150 \mathrm{mg}$ per $3 \mathrm{~kg}$ of animal weight once a day for three days in a single dose. Puppies of the second experimental group were fed the drug "Fenbenzyl" at a dose of $350 \mathrm{mg}$ per $3 \mathrm{~kg}$ of animal weight once a day for three days. In the clinical manifestation of the disease, toxocariasis secretes metabolic products that promote the formation of large amounts of free radicals, which in turn enhance the initiation of lipid peroxidation processes. With the use of fenbendazole and fenbenzyl, a probable decrease in these products was found starting from the 15th day of the experiment. It should be noted that the lowest level of diene conjugates and TBA-active products was in the blood of dogs of the second experimental group at 25 and 30 days of the experiment. Inhibition of lipid peroxidation processes in the treatment of dogs with fenbenzyl is due to the activation in animals of metabolic processes involving enzymes, including antioxidant enzymes that catalyze the processes of peroxidation and phosphorylation, as well as enhancing erythropoietic function. On the 30th day of the experiment, the level of diene conjugates in the blood of the second experimental group was $0.29 \pm 0.02 \mathrm{IU} / \mathrm{ml}$, and TBA-active products $-25.2 \pm 0.40 \mu \mathrm{mol} / \mathrm{l}$.

Key words: toxocariasis, dogs, lipid peroxidation, fenbendazole, fenbenzyl.

\section{Вплив фенбенсилу та фенбендазолу на інтенсивність пероксидного окиснення ліпідів у крові собак за експериментального токсокарозу}

\author{
В. В. Стибель, Б. В. Гутий, В. С. Саід
}

Львівський національний університет ветеринарної медицини та біотехнологій імені С. 3. Гљицького, м. Львів, Украӥна

Токсокароз - гельмінтозне захворювання із хронічним перебігом, викликане личинковими стадіями нематоди Тохосага сапіs. Проблема токсокарозу є важливою, як для гуманної, так $і$ для ветеринарної медицини. Тому, метою роботи було дослідити вплив фенбенсилу та фенбендазолу на інтенсивність пероксидного окиснення ліпідів у крові собак за експериментального інвазування збудником токсокарозу. Досліди проводили на 18 собаках, дво-чотиримісячного віку та сформовано три групи з шести тварин у кожній: контрольну та дві дослідні групи. Цуценят усіх груп експериментально заражсали збудником токсокарозу у дозі 5000 інвазійних яєць T. сапіs на кг маси тіла. Контрольна група собак була в якості нелікованого контролю. Цуценятам першої дослідної групи 
згодовували препарат “Фенбендазол” у дозі 150 мг на 3 кг маси тварини один раз на добу протягом трьох днів в одноразовій дозі. Цуиенятам другої дослідної групи згодовували препарат “Фенбенсил” у дозі 350 мг на 3 кг маси тварини один раз на добу протягом трьох днів. За клінічного прояву хвороби токсокари виділяють продукти метаболізму, які сприяють утворенню великої кількості вільних радикалів, щуо у свою чергу посилюють ініціаџію процесів пероксидного окиснення ліпідів. При застосуванні фенбендазолу та фенбенсилу встановлено вірогідне зниження даних продуктів вже починаючи з 15 доби досліду. Варто зазначити, шяо найнижчий рівень дієнових конюгатів та ТБК-активних продуктів був у крові собак другої дослідної групи на 25 і 30 доби досліду. Пригнічення прочесів пероксидного окиснення ліпідів за лікування собак фенбенсилом зумовлене активацією в організмі тварин метаболічних процесів, у яких приймають участь ензими, у тому числі і ензими-антиоксиданти, щзо каталізують процеси пероксидного окиснення і фосфорилювання, а також посилення еритропоетичної функиї̈ кісткового мозку. На 30 добу досліду рівень дієнових кон 'югатів у крові другої дослідної групи становив 0,29 0,02 одА/мл, а ТБК-активних продуктів - 25,2 \pm 0,40 мкмоль/л.

Ключові слова: токсокароз, собаки, пероксидне окиснення ліпідів, фенбендазол, фенбенсил.

\section{Вступ}

Серед інвазійних хвороб собак найбільш поширеними на території нашої країни та за їі межами $\epsilon$ шлунково-кишкові гельмінтози, серед яких провідне місце займає токсокароз - нематодозна інвазія 3 підряду Ascaridata (Bodnia, 2016; Dralova et al., 2017).

За останнє десятиліття у зв'язку з прогресивним зростанням чисельності собак, ї безконтрольним утриманням і масовим забрудненням навколишнього середовища інвазійним матеріалом - фекаліями, дане захворювання стало серйозною медико-соціальною проблемою для багатьох країн світу, зокрема, і України (Dralova et al., 2017; Said et al., 2020).

Toxocara canis (аскарида собак) живе в тонкому кишечнику і харчується його вмістом. Харчуватися вона може, як через рот, так і всією поверхнею тіла. Масова міграція личинок в організмі дорослих собак (особливо вагітних сук) і цуценят призводить до ураження судин слизової кишечника і багатьох органів, у тому числі й плаценти. У разі значної інтенсивності інвазії дорослі паразити спричинюють запалення слизової оболонки тонких кишок, шлунку, жовчних ходів печінки та підшлункової залози. Токсокари виділяють токсини, які, всмоктуючись в кров, спричинюють загальну інтоксикацію організму (Usachova \& Dralova, 2012; Rubinsky-Elefant et al., 2011; Lovytskaia et al., 2013; Said et al., 2018).

Встановлено, що максимальну ураженість збудником токсокарозу зареєстровано у цуценят до 6місячного віку - 85 \%. Дещо нижчою виявилась екстенсивність інвазії у тварин 6-9-місячного віку (61,5 \%) та у віці 9-12 місяців, що становить 45,4 \%. В подальшому з віком собак показники їх інвазованості знижувалися (25 \% у віці від 1-го до 2-х років). Найнижчий рівень інвазованості зареєстровано у дорослих тварин, переважно у вагітних самок віком понад 3 роки (11 \%) (Stybel \& Pryima, 2010; Moisieieva et al., 2017).

За ларвального токсокарозу цуценят встановлено порушення гемопоезу та функціонального стану печінки і підшлункової залози, що характеризуються зниженням кількості еритроцитів, вмісту гемоглобіну, гематокритної величини. Встановлено, що інвазія Toxocara canis та іiі метаболіти проявляють мутагенну дію на хромосомний апарат соматичних клітин нелінійних білих щурів, що призводить до вірогідного збільшення кількості еритроцитів із мікроядрами (Ozlati et al., 2016; Noor et al., 2019).
Аналізуючи окремі показники морфологічного складу крові, слід зазначити, що у хворих цуценят встановлені лейкоцитоз, олігоцитемія, олігохромемія та нормохромія. Окрім загальноклінічних показників, у хворих на ларвальний токсокароз тварин відмічали зміни біохімічного складу. За біохімічного дослідження були встановлені: гіперпротеїнемія, зниження вмісту сечовини, активності $\alpha$-амілази й ліпази, зростання активності АсАТ і АлАТ, вмісту глюкози та холестеролу (Pryima, 2010; Zakharchuk \& Harazdiuk, 2014).

Наявна література, яка відображає численні результати досліджень впливу токсокар та їх метаболітів на організм тварин, не повністю відображає ї механізм дії. Дослідження проводилися на тваринах 3 метою розкриття порушень функції серцево-судинної системи, центральної нервової системи та травного тракту за розвитку токсокарозної інвазії (Svirzhevska, 2011; 2013). Деякими вченими було встановлено складність патогенезу токсокарозу у тварин: розлади обміну речовин, порушення фізіологічних функцій організму, також було запропоновано різні способи лікування тварин за даної патології. Зокрема, досі залишається не виясненим питання про вплив токсокар та їх метаболітів на одну з важливих, захисних систем організму - антиоксидантну систему, завданням якої $є$ підтримання балансу між інтенсивністю радикалоутворення та потребами організму у фізіолого-біохімічних аспектах дії радикалів кисню та їх похідних, а саме синтезу біологічно-активних речовин, регуляції проникності мембран (Stybel et al., 2019; Grymak et al., 2020; Varkholiak et al., 2021).

Пероксидне окиснення ліпідів $є$ одним із найважливіших окиснювальних процесів в організмі собак. Нині даний процес вважається одним з основних причин пошкодження та загибелі клітини внаслідок негативної дії активних форм кисню (Gutyj et al., 2017; 2018; Varkholiak \& Gutyj, 2019). Будь-який достатньо потужний вплив на організм тварин, в тому числі розвиток токсокарозу, може ініціювати процеси пероксидного окиснення ліпідів (Lesyk et al., 2020). Таким чином процеси пероксидного окиснення ліпідів розглядають як один із важливих механізмів клітинної патології (Martyshchuk \& Gutyi, 2019; Slobodian et al., 2019), що лежить в основі розвитку токсокарозу у собак. Певну роль у розвитку патології відіграють вторинні та кінцеві продукти пероксидного окиснення, які мають цитотоксичні та мутагені ефекти (Martyshuk et al., 2018; 2019; 2021; Martyshuk \& Hutyi, 2021). До них належать дієнові кон'югати та ТБК- 
активні продукти. У ході даного процесу зі стабільних молекул ліпідів утворюються ліпідні радикали, які у подальшому піддаються поступовому руйнуванню (Shcherbatyy et al., 2019; Varkholiak \& Gutyj, 2020; Nazaruk et al., 2021).

Саме тому метою роботи було дослідити вплив фенбенсилу та фенбендазолу на інтенсивність пероксидного окиснення ліпідів у крові собак за експериментального інвазування збудником токсокарозу.

\section{Матеріал і методи досліджень}

Роботу виконували впродовж 2017-2020 років на кафедрі паразитології та іхтіопатології Львівського національного університету ветеринарної медицини та біотехнологій імені С. З. Гжицького. Досліди проводили на 18 собаках, дво-чотиримісячного віку та сформовано три групи з шести тварин у кожній: контрольну та дві дослідні групи. Цуценят усіх груп експериментально заражали збудником токсокарозу у дозі 5000 інвазійних яєць T. canis на кг маси тіла. Контрольна група собак була в якості нелікованого контролю. Цуценятам першої дослідної групи згодовували препарат “Фенбендазол” у дозі 150 мг на 3 кг маси тварини один раз на добу протягом трьох днів в одноразовій дозі. Цуценятам другої дослідної групи згодовували препарат “Фенбенсил” (ТУ У 00492990-027:2020 Препарат “Фенбенсил”) у дозі 350 мг на 3 кг маси тварини один раз на добу протягом трьох днів.

Препарат “Фенбенсил” було розроблено на кафедpi фармакології та токсикології та кафедрі паразитології та іхтіопатології Львівського національного університету ветеринарної медицини та біотехнологій імені С. 3. Гжицького, який у своєму складі містить фенбендазол та розторопшу плямисту.

Рівень дієнових кон'югатів (ДК) визначали за методом І. Д. Стальної (1977); рівень ТБК-активних продуктів - за методом Є. Н. Коробейникова (Vlizlo et al., 2012).

Усі маніпуляції з тваринами проводили відповідно до Європейської конвенції про захист хребетних тварин, які використовуються для експериментальних і наукових цілей (Страсбург, 1986 р.).

Аналіз результатів досліджень проводили за допомогою пакету програм Statistica 6.0. Вірогідність різниць оцінювали за t-критерієм Стьюдента. Результати середніх значень вважали статистично вірогідними при $*_{-} \mathrm{P}<0,05, * *-\mathrm{P}<0,01, * * *-\mathrm{P}<0,001$ (ANOVA).

\section{Результати та їх обговорення}

У механізмах дії багатьох інвазійних захворювань суттєву роль відіграє активація процесів пероксидного окиснення ліпідів. Пероксидне окиснення ліпідів це окиснювальна деградація ліпідів, яка відбувається під дією вільних радикалів, та $є$ однією $з$ основних причин пошкодження мембран клітин та у подальшому загибелі клітин унаслідок впливу активних форм кисню. Встановлено, що за розвитку токсокарозу у собак посилюються процеси пероксидного окиснення ліпідів, на що вказують зростання рівня продуктів ПОЛ, а саме дієнових кон'югатів та ТБК-активних продуктів. Так на 25 добу досліду у крові контрольної групи собак встановлено підвищення рівня дієнових кон'югатів у 2,58 разів (табл. 1) та ТБК-активних продуктів - на 43,3 \% відносно початкових величин (табл. 2).

\section{Таблиця 1}

Вплив фенбенсилу та фенбендазолу на рівень дієнових кон'югатів у крові собак, інвазованих збудником токсокарозу $(\mathrm{M} \pm \mathrm{m}, \mathrm{n}=6)$

\begin{tabular}{cccc}
\hline \multirow{2}{*}{ Час дослідження крові } & \multicolumn{3}{c}{ ДК, одА/мл } \\
\cline { 2 - 4 } (доби) & Контрольна & Групи тварин & Дослідна 2 \\
\cline { 2 - 3 } & $0,26 \pm 0,01$ & $0,24 \pm 0,02$ & $0,27 \pm 0,02$ \\
До лікування & $0,38 \pm 0,03$ & $0,33 \pm 0,01$ & $0,30 \pm 0,03$ \\
5 доба & $0,43 \pm 0,03$ & $0,36 \pm 0,02$ & $0,32 \pm 0,04$ \\
10 доба & $0,51 \pm 0,03$ & $0,42 \pm 0,03^{*}$ & $0,38 \pm 0,02^{* *}$ \\
15 доба & $0,60 \pm 0,04$ & $0,46 \pm 0,02^{* *}$ & $0,36 \pm 0,03^{* * *}$ \\
20 доба & $0,67 \pm 0,02$ & $0,43 \pm 0,01^{* * *}$ & $0,34 \pm 0,03^{* * *}$ \\
25 доба & $0,76 \pm 0,05$ & $0,38 \pm 0,02^{* * *}$ & $0,29 \pm 0,02^{* * *}$ \\
30 доба &
\end{tabular}

При дослідженні рівня дієнових кон'югатів у собак дослідних груп встановлено, що на початку досліду даний показник коливався у межах $0,24 \pm 0,02-$ $0,27 \pm 0,02$ одА/мл. У подальшому встановлено підвищення рівня проміжних продуктів ПОЛ. Так, на 5 добу досліду рівень дієнових кон'югатів зріс на 37,5 i 11,1 \% порівняно з показниками взятими на початку досліду. На 15 добу досліду рівень показника, що досліджувався, становив у першої дослідної групи $26,0 \pm 0,35$ мкмоль/л, а у другої дослідної групи 25,4 \pm 0,40 мкмоль/л відповідно.
Застосування препаратів “Фенбенсилу” та “Фенбендазолу” інвазованим собакам сприяло зниженню проміжних продуктів ПОЛ, де відповідно на 20 добу досліду рівень дієнових кон'югатів у крові другої дослідної групи знизився на 40 \%, тоді як у першої 23,3 \% відповідно. На 30 добу досліду встановлено зниження рівня дієнових кон'югатів у першої дослідної групи до 0,38 \pm 0,02 мкмоль/л, однак до фізіологічних величин даний показник не доходив. Лише застосування фенбенсилу собакам за розвитку токсокарозу встановлено зниження рівня дієнових кон'югатів до фізіологічних величин. 
Таблиця 2

Вплив фенбенсилу та фенбендазолу на рівень ТБК-активних продуктів у крові собак, інвазованих збудником токсокарозу $(\mathrm{M} \pm \mathrm{m}, \mathrm{n}=6)$

\begin{tabular}{cccc}
\hline \multirow{2}{*}{ Час дослідження крові } & \multicolumn{3}{c}{ ТБК-активні продукти, мкмоль/л } \\
\cline { 2 - 4 } (доби) & Контрольна & Групи тварин & Дослідна 1 \\
\cline { 2 - 4 } & $24,7 \pm 0,34$ & $25,0 \pm 0,30$ & $24,9 \pm 0,31$ \\
До лікування & $25,9 \pm 0,41$ & $25,4 \pm 0,28$ & $25,2 \pm 0,35$ \\
5 доба & $30,4 \pm 0,25$ & $25,9 \pm 0,30^{* *}$ & $25,5 \pm 0,26^{* * *}$ \\
10 доба & $31,8 \pm 0,55$ & $26,0 \pm 0,35^{* * *}$ & $25,4 \pm 0,40^{* * *}$ \\
15 доба & $33,0 \pm 0,61$ & $28,3 \pm 0,42^{* * *}$ & $25,8 \pm 0,37^{* * *}$ \\
20 доба & $35,4 \pm 0,56$ & $29,9 \pm 0,38^{* * *}$ & $26,5 \pm 0,25^{* * *}$ \\
25 доба & $42,5 \pm 0,47$ & $30,5 \pm 0,31^{* * *}$ & $25,2 \pm 0,40^{* * *}$ \\
\hline 30 доба &
\end{tabular}

При дослідженні кінцевих продуктів ПОЛ встановлено, що у крові першої дослідної групи на 10 добу досліду рівень ТБК-активних продуктів знизився на 14,8 \%, а у другої дослідної групи - на 16,1 \% відносно контрольної групи тварин. У подальшому рівень кінцевих продуктів ПОЛ продовжував знижуватися у всіх дослідних групах. Однак варто зазначити, що при застосуванні фенбенсилу собакам другої дослідної групи рівень ТБК-активних продуктів був нижчим ніж у першої дослідної групи, яким згодовували фенбендазол. Так, на 20 і 25 доби досліду рівень ТБКактивних продуктів у крові другої дослідної групи знизився на 21,8 і 25,1 \%, а у першої дослідної групи відповідно - на 14,2 і 15,5 \% відносно контрольної групи.

\section{Висновки}

За клінічного прояву хвороби токсокари виділяють продукти метаболізму, які сприяють утворенню великої кількості вільних радикалів, що у свою чергу посилюють ініціацію процесів пероксидного окиснення ліпідів. На це вказує зростання продуктів ПОЛ та пригнічення активності показників ензимної та неензимної ланки антиоксидантного захисту у крові інвазованих собак.

При застосуванні інвазованим собакам фенбендазолу та фенбенсилу встановлено вірогідне зниження продуктів ПОЛ вже починаючи 315 доби досліду. Варто зазначити, що найнижчий рівень дієнових конюгатів та ТБК-активних продуктів був у крові собак другої дослідної групи на 25 і 30 доби досліду.

\section{References}

Bodnia, I. P. (2016). Stan adaptyvno-kompensatornykh mozhlyvostei orhanizmu liudyny pry toksokarozi. Hepatolohiia, 4, 19-33. URL: http://nbuv.gov.ua/ UJRN/gepat_2016_4_4 (in Ukrainian).

Dralova, O. A., Usachova, O. V., \& Konakova, O. V. (2017). Koreliatsiini vzaiemozviazky imunolohichnykh ta kliniko-laboratornykh pokaznykiv patsiientiv iz toksokaroznoiu invaziieiu. Aktualnaia infektolohiya, 5(5), 235-238. URL: http://nbuv.gov.ua/UJRN/akinf_2017_5_5_12 (in Ukrainian).
Dralova, O. A., Usachova, O. V., Silina, Ye. A., \& Konakova, O. V. (2017). Suchasnyi pohliad na problemu toksokaroznoi invazii $u$ ditei (ohliad literatury). Sovremennaja pediatrija, 3, 53-61. URL: http://nbuv.gov.ua/UJRN/Sped_2017_3_10 (in Ukrainian).

European convention for the protection of vertebrate animals used for experim. and other scientific purposes (1986). Coun. of Europe, 53.

Grymak, Y., Skoromna, O., Stadnytska, O., Sobolev, O., Gutyj, B., Shalovylo, S., Hachak, Y., Grabovska, O., Bushueva, I., Denys, G., Hudyma, V., Pakholkiv, N., Jarochovich, I., Nahirniak, T., Pavliv, O., Farionik, T., \& Bratyuk, V. (2020). Influence of "Thireomagnile" and "Thyrioton" preparations on the antioxidant status of pregnant cows. Ukrainian Journal of Ecology, 10(1), 122-126. doi: 10.15421/2020 19.

Gutyj, B. V., Gufriy, D. F., Binkevych, V. Y., Vasiv, R. O., Demus, N. V., Leskiv, K. Y., Binkevych, O. M., \& Pavliv, O. V. (2018). Influence of cadmium loading on glutathione system of antioxidant protection of the bullocks'bodies. Scientific Messenger of Lviv National University of Veterinary Medicine and Biotechnologies, 20(92), 34-40. doi: 10.32718/nvlvet9207.

Gutyj, B., Stybel, V., Darmohray, L., Lavryshyn, Y., Turko, I., Hachak, Y., Shcherbatyy, A., Bushueva, I., Parchenko, V., Kaplaushenko, A., \& Krushelnytska, O. (2017). Prooxidant-antioxidant balance in the organism of bulls (young cattle) after using cadmium load. Ukrainian Journal of Ecology, 7(4), 589-596. URL: https:/www.ujecology.com/abstract/prooxidantantioxi dant-balance-in-the-organism-of-bulls-young-cattleafter-using-cadmium-load-693.html.

Lesyk, Y., Ivanytska, A., Kovalchuk, I., Monastyrska, S., Hoivanovych, N., Gutyj, B., Zhelavskyi, M., Hulai, O., Midyk, S., Yakubchak, O., \& Poltavchenko, T. (2020). Hematological parameters and content of lipids in tissues of the organism of rabbits according to the silicon connection. Ukrainian Journal of Ecology, 10(1), 30-36. doi: 10.15421/2020_5.

Lovytskaia, L. H., Semenchenko, S. L., Malysh, P. N., Sulzhenko, M. Iu., Maliutenko, K. P., Beletskaia, L. M., \& Kuznetsov, A. V. (2013). Otsenka faktorov ryska vozmozhnosty zarazhenyia toksokarozom naselenyia Luhanskoi oblasty. Zdorove rebenka, 8, 14-18. URL: http://nbuv.gov.ua/UJRN/Zd_2013_8_5 (in Ukrainian). 
Martyshchuk, T. V., \& Gutyi, B. V. (2019). Influence of feed additive "Butaselmevit Plus" on the indicators of rats blood under the conditions of their poisoning with Tetrachloromethane. Theoretical and Applied Veterinary Medicine, 7(2), 79-83. doi: 10.32819/2019.71014.

Martyshuk, T. V., \& Hutyi, B. V. (2021). Imunofiziolohichnyi stan ta antyoksydantnyi potentsial orhanizmu porosiat za umov oksydatsiinoho stresu ta dii koryhuiuchykh chynnykiv: monohrafiia. Lviv: SPOLOM (in Ukrainian).

Martyshuk, T. V., Gutyj, B. V., \& Vishchur, O. I. (2018). Indicators of functional and antioxidant liver status of rats under oxidative stress conditions and on the action of the liposomal drug "Butaselmevit". Scientific Messenger of Lviv National University of Veterinary Medicine and Biotechnologies, 20(89), 100-107. doi: $10.32718 /$ nvlvet8919.

Martyshuk, T. V., Gutyj, B. V., Leskiv, Kh. Ya., Semaniuk, N. V., \& Shnaider, V. L. (2021). The effect of the liposomal drug "butaselmevit" on the enzymatic and non-enzymatic part of the glutatoin system of the blood of rats under oxidative stress. Colloquiumjournal, 12(99), 16-19.

Martyshuk, T. V., Gutyj, B. V., Vishchur, O. I., \& Todoriuk, V. B. (2019). Biochemical indices of piglets blood under the action of feed additive "Butaselmevitplus". Ukrainian Journal of Veterinary and Agricultural Sciences, 2(2), 27-30. doi: 10.32718/ujvas2-2.06.

Moisieieva, N. V., Kapustianska, A. A., Vakhnenko, A. V., Rumiantseva, M. O., \& Kulyk, L. H. (2017). Toksokaroz - suchasni aspekty problemy. Aktualni problemy suchasnoi medytsyny, 17, 4(1), 272-277. URL: http://nbuv.gov.ua/UJRN/apsm_2017_17_4 (1)__ 63 (in Ukrainian).

Nazaruk, N. V., Gutyj, B. V., Gufrij, D. F., Leskiv, Kh. Ya., Ivashkiv, R. M., \& Martyshuk, T. V. (2021). The effect of methyphen and vitamix se on the level of products of bull lipid peroxide oxidation under nitratecadmium load. Colloquium-journal, 7(94), 16-18. doi: 10.24412/2520-6990-2021-794-16-18.

Noor, J., Abbas, A. K., \& Aảiz, N. N. (2019). Serodiagnosis of Toxocariasis by ELISA test using anti- T. canis IgG antibodies in stray dogs compared to PCR. Iraqi Journal of Veterinary Sciences, 33(2), 367-370. doi: 10.33899/ijvs.2019.163081.

Ozlati, M., Spotin, A., Shahbazi, A., Mahami-Oskouei, M., Hazratian, T., Adibpor, M., Ahmadpour, E., Dolatkhah, A., \& Khoshakhlagh, P. (2016). Genetic variability and discrimination of low doses of Toxocara spp. from public areas soil inferred by loopmediated isothermal amplification assay as a fieldfriendly molecular tool. Veterinary World, 9(12), 1471-1477 doi: 10.14202/vetworld.2016.1471-1477.

Pryima, O. B. (2010). Osoblyvosti poshyrennia toksokarozu sobak za yikh vikovoiu dynamikoiu. Naukovyi visnyk Lvivskoho natsionalnoho universytetu veterynarnoi medytsyny ta biotekhnolohii im. Gzhytskoho, 12(2), 254-257. URL: http://nbuv.gov.ua/UJRN/nvlnu_2010_12_2(1)_53 (in Ukrainian).
Rubinsky-Elefant, G., Hoshino-Shimizu, S., Jacob, C. M. A., Sanchez, M. C. A., \& Ferreira, A. W. (2011). Potential immunological markers for diagnosis and therapeutic assessment of toxocariasis. Revista do Instituto de Medicina Tropical de São Paulo, 53(2), 61-65. doi: 10.1590/S0036-46652011000200001.

Said, W. S., Stybel, V. V., Gytyj, B. V., Pryima, O. B., Sobolta, A. G., Leskiv, K. Y., \& Dytiuk, M. P. (2020). The state of the immune system of dogs in experimental toxocariasis. Ukrainian Journal of Veterinary and Agricultural Sciences, 3(3), 20-24. doi: 10.32718/ujvas33.04 .

Said, W., Stybel, V. V., Gutyj, B. V., \& Prijma, O. B. (2018). A modern look at the problem of toxocarosis in dogs. Scientific Messenger of Lviv National University of Veterinary Medicine and Biotechnologies, 20(83), 411-416. doi: 10.15421/nvlvet8380.

Shcherbatyy, A. R., Slivinska, L. G., Gutyj, B. V., Fedorovych, V. L., \& Lukashchuk, B. O. (2019). Influence of Marmix premix on the state of lipid peroxidation and indices of non-specific resistance of the organism of pregnant mares with microelementosis. Regulatory Mechanisms in Biosystems, 10(1), 87-91. doi: 10.15421/021914.

Slobodian, S. O., Gutyj, B. V., \& Leskiv, K. Y. (2019). The level of lipid peroxidation products in the rats blood under prolonged cadmium and lead loading. Ukrainian Journal of Veterinary and Agricultural Sciences, 2(3), 15-18. doi: 10.32718/ujvas2-3.04.

Stybel, V. V., \& Pryima, O. B. (2010). Vplyv toksokaroznoi invazii na chastotu vyiavlennia mikroiader $\mathrm{V}$ erytrotsytakh bilykh neliniinykh shchuriv u mikroiadernomu testi. Veterynarna medytsyna, 93, 373-377. URL: http://nbuv.gov.ua/ UJRN/vetmed_2010_93_80 (in Ukrainian).

Stybel, V., Gutyj, B., Hariv, I., Slivinska, L., \& Prijma, O. (2019). Effect of "Amprolinsyl" and "Amprolium $22 \%$ " on morphological indices of blood of turkeys for eumeria invasion. Scientific Messenger of Lviv National University of Veterinary Medicine and Biotechnologies. Series: Veterinary sciences, 21(94), 157-162. doi: 10.32718/nvlvet9429.

Svirzhevska, Ye. L. (2011). Etiotropna ta patohenetychna terapiia myslyvskykh sobak za larvalnoho toksokarozu. Naukovyi visnyk Lvivskoho natsionalnoho universytetu veterynarnoi medytsyny ta biotekhnolohii im. Gzhytskoho, 13(4), 375-381. URL: http://nbuv.gov.ua/UJRN/nvlnu_2011_13_4(1)_71 (in Ukrainian).

Svirzhevska, Ye. L. (2013). Patohenez i likuvannia tsutseniat za toksokaroznoi invazii. Veterynarna medytsyna Ukrainy. 1, 24-27. URL: http://nbuv.gov.ua/UJRN/vetm_2013_1_9 (in Ukrainian).

Usachova, O. V., \& Dralova, O. A. (2012). Analiz osoblyvostei epidemichnoho protsesu toksokarozu v Zaporizkii oblasti v 2007-2009 rokakh. Zaporozhskyi medytsynskyi zhurnal, 2, 62-65. URL: http://nbuv.gov.ua/UJRN/Zmzh_2012_2_17 (in Ukrainian).

Varkholiak, I. S., \& Gutyj, B. V. (2019). Influence of the preparation "Bendamin" on the indicators of 
antioxidant protection of rat myocardium in experimental modeling of heart failure. Scientific Messenger of Lviv National University of Veterinary Medicine and Biotechnologies. Series: Veterinary sciences, 21(95), 98-101. doi: 10.32718/nvlvet9518.

Varkholiak, I. S., \& Gutyj, B. V. (2020). The influence of the preparation "Bendamin" on the morphological and biochemical indices of blood of rats in experimental modeling of heart failure. Ukrainian Journal of Veterinary and Agricultural Sciences, 3(1), 38-41. doi: 10.32718/ujvas3-1.07.

Varkholiak, I. S., Gutyj, B. V., Leskiv, Kh. Ya., Kushnir, V. I., Hariv, I. I., Martyshuk, T. V., \& Guta, Z. A.
(2021). The effect of bendamine on antioxidant protection of rats' myocardium in doxorubicin intoxication. Colloquium-journal, 7(94), 18-21. doi: 10.24412/2520-6990-2021-794-18-21.

Vlizlo, V. V., Fedoruk, R. S., \& Ratych, I. B. (2012). Laboratorni metody doslidzhen u biolohii, tvarynnytstvi ta veterynarnii medytsyni. Dovidnyk. za red. Vlizla, V.V. Lviv. SPOLOM (in Ukrainian).

Zakharchuk, O. I., \& Harazdiuk, H. V. (2014). Problemy toksokarozu liudyny i tvaryn na Bukovyni. Veterynarna medytsyna Ukrainy, 7, 38-39. URL: http://nbuv.gov.ua/UJRN/vetm_2014_7_12 (in Ukrainian). 